\title{
Use of frozen boar semen in practice
}

\author{
M. PAQUIGNON $\left({ }^{2}\right)$, J. BUSSIERE $\left({ }^{2}\right)$, F. BARITEAL $\left({ }^{2}\right)$ et M. (OUROT $\left({ }^{3}\right)$ \\ (1) I.T.P., I 19, rue de Bercy, 75579 Paris Cedex I2 \\ (2) I.N.R.A.-S.E.I.A., 86,80 Rouille (France) \\ (3) Station de Physiologie de la Reproduction, I.N.R.A., $373^{80}$ Nonsilly (France)
}

\begin{abstract}
A technique of semen freezing and use of the frozen semen after variable storage length were tested in practice. Inseminations were performed by trained technicians. About $5^{8}$ per cent of the inseminated sows produced 9.7 piglets. However, there were differences between the boars. Hence, semen of Large White boars as compared with that of Landrace boars significantly improved the farrowing rate $(67$ per cent versus 48 per cent). Prolificacy was not significantly improved. According to the results obtained a further development of this new technique of low temperature storage of semen should be possible, notably as no lowering of fertility was recorded all along the period of storage.
\end{abstract}

\section{Control of the sexual cycles of nulliparous gilts by means of norethandrolone and prostaglandin analogue (I CI 80996)}

\author{
Françoise MARTINAT-BOTTE (1), A. I.OCATELLI ('), P. MAUI.ÉON (2) \\ (1) I.T.P., I 49, rue de Bercy, 75579 Paris Cedex I2 \\ (2) Station de Physiologie de la Reproduction, I.N.R.A., 37380 Nonizlly (Irance)
}

\begin{abstract}
Daily injection of $3^{\circ} \mathrm{mg}$ norethandrolone for 18 days allowed a grouping of oestruses over 72 hours in 79.2 per cent of the treated females. The first heats appeared 5 days after the end of the treatment. Fertility after induced oestrus was 75 per cent. When administration of the progestagen was restricted to 9 days, oestrus, synchronisation over 72 hours only slightly differed from that of a long treatment if a prostaglandin analogue ( 2 injections of $500 \mu \mathrm{g}$ of ICI 80996 ) was injected on the day when the progastagen administration ceased. This prostaglandin analogue destructed the corpora lutea persisting at the end of the short treatment started on the first 5 days of the cycle. The fertility of this controlled oestrus was 81.8 per cent. The practical value of these treatments remains limited, but the results obtained show that:

-- use of a progestagen for a long time does not modify the fertility of this oestrus,

-.- prostaglandins are active on a corpus luteum aged 1o-1 4 days.
\end{abstract}

\section{Control of the sexual cycles of nulliparous gilts. Comparison of two progestagens : Norethandrolone and RU 2267}

\author{
Françoise MARTINAT-BOTTE (1), P. MALLÉON (2) et J. GALTIER ( $\left.{ }^{2}\right)$ \\ (1) I.T.P., 149, rue de Bercy, 75579 Paris Cedex I2 \\ (2) Station de Physiologit de la Reproduction, I.N.R.A., 37380 Nousilly (France)
}

Two progestagens, norethandrolone (derived from nortestosterone) and RU 2267 (derived from progesterone) were administered orally for i 8 days to nulliparous gilts. The animals were inseminated twice after induced oestrus; gestation was checked at 30 days, after slaughter. 